\title{
PSYCHOMETRIC PROPERTIES OF TRAVELERS NEEDS QUESTIONNAIRE (TNQ)
}

\author{
Jel̦ena L̦evina \\ Jel̦ena Koḷesņikova \\ Rīga Stradiņš University, Latvia \\ Tatjana Kanonire \\ National Research University Higher School of Economics, Russia
}

\begin{abstract}
The purpose of this research was to develop the Travelers Needs Questionnaire (TNQ), which measures travelers' needs, and to determine its psychometric properties. The $T N Q$ was developed for travelers with native Russian language from different countries: Russia, Belarus, Ukraine, the Baltic States. The sample consisted of 237 participants aged from 17 to 68 years (26.2\% male, $73.8 \%$ female, mean age $M=30.49, S D=9.21)$. The factorial validity of the TNQ was established using principal components analysis with varimax rotation; this yielded seven factors: Professional Realization, Pilgrimage, Personal Development, Cultural Development, Sport, Physical Hedonism and Communication. All the $T N Q$ scales had high internal consistency. The reaction and discrimination indices satisfied the accepted psychometric criteria. The further stage of the TNQ development would be the confirmatory factor analysis in broader international sample, the concurrent and convergent validity establishing, and test-retest reliability examination.
\end{abstract}

Keywords: travelers' needs, factorial validity, reliability.

\section{Introduction}

The explaining and prediction of travelers' behaviour is an actual task, which is related to qualitative planning of work, rest and leisure, business and pleasure. The understanding and measurement of factors that arouses and direct travelers behaviour are important for more effective planning and realization of tourism marketing strategy.

The area of travel motivation has been recognized as fundamental in tourism studies (McIntosh, Goeldner \& Ritchie, 1995; Pearce, 2005; Wahab, 1975). Tourist motivation is defined as "a dynamic process of internal psychological factors (needs and wants) that generate a state of tension or disequilibrium within individuals" (Crompton \& McKay, 1997, p. 427), "cause a person to act in a certain way or stimulate their interest in travel and participation in a tourist activity" (Kim \& Eves, 2012, p. 1458).

Tourist motivations are linked with tourists' perception of destinations (Matzler, K. \& Siller, 2003). Tourist motivations influence the selection of a 
vacation destination (Crompton, 1979; Moscardo, G., Morrison, Pearce, Lang \& O'Leary, 1996), as well as participation in a certain range of activities and choice of certain types of tourism attractions, such as getting to know local inhabitants, taking short guided excursion, touring the countryside, visiting wilderness areas, mountains, national parks and forests, galleries and museums, seeing historic and archaeological sites and sightseeing in cities, engaging in sunbathing, beach activity, swimming and visiting entertainment places, taking pictures/films, dining out, attending sporting events (Moscardo et al., 1996), visiting festivals (Crompton \& McKay, 1997; Mohr, Backman, Gahan \& Backman, 1993; Uysal, Gahan \& Martin, 1993). Tourist motives determine consumption of local food and beverages in a tourist destination (Kim \& Eves, 2012).

Thus, there is evidence that human needs are important factors in explaining and prediction of travelers' preferences and activities. However, there is a lack of such available instruments, which measure travelers' needs and can be appropriate in the multicultural context, especially for use with travelers whose native language is Russian. Therefore, this study aims to develop a measurement instrument that can be used to measure needs of travelers with native Russian language.

\section{Travelers' needs and tourist motivation}

Theoretical and empirical research on tourist motivations has shown that there exist certain groups of human needs, which determine travelers' preferences and activities.

McIntosh, Goeldner, and Ritchie (1995) synthesized previous studies on tourist motivations and described four categories of motivators: physical, cultural, interpersonal and status and prestige motivators. The physical motives are reducing physical tension, refreshing a person's body and mind, physical rest, desire for recreation, participation in sports. The cultural motives include a desire to experience different cultures and to gain knowledge about other countries. The interpersonal motives refer to a desire to meet new people, spend time with family and friends, visit friends or relatives, or get away from the routine relationships. At last, the status and prestige motives refer to self-esteem, recognition and the desire to attract attention from others.

Pearce and co-authors have developed two models of travelers' needs: the travel career ladder (TCL) and the travel career pattern (TCP) (Pearce, 2005). The TCL (Moscardo \& Pearce, 1986; Pearce, 1988, 1993; Pearce \& Caltabiano, 1983) is an older model of travel motivation, which is based on Maslow's (1970) needs hierarchy theory of motivation. According to the TCL tourist motivation consists of five levels: relaxation needs, safety/security needs, 
relationship needs, self-esteem and development needs, and self-actualization/ fulfilment needs; the needs are organized into a hierarchy, and one set of needs in this hierarchy might be dominant.

The TCP (Pearce, 2005) is modified TCL with more emphasis on the change of motivation patterns reflecting career levels than on the hierarchical levels. Travelers exhibit changing motivational patterns over their life-stages and/or with travel experience. Travel motivation seems to have been identified as patterns and combinations of multiple motives. In the empirical research (Pearce \& Lee, 2005) fourteen motivation factors were identified: novelty, escape/relax, relationship (strengthen), autonomy, nature, self-development (host-site involvement), stimulation, self-development (personal development), relationship (security), self-actualisation, isolation, nostalgia, romance and recognition.

Thus, travel motivation can be viewed as a multidimensional construct comprising numerous motives.

\section{Questionnaire development}

In psychology scientists traditionally recognize three aspects of Self and respectively three fields of functioning of the personality: physical or material, social and spiritual (James, 1890). In turn, it is recognized, that human needs also exist at three levels: psychophysiological, social and spiritual (Nuttin, 1962). In this light, as well as taking into account previous studies on tourist motivations, it is possible to conceptualize travelers' needs within three categories: psychical needs (e.g., relaxation needs, health concern, thrill seeking), social needs (e.g., prestige seeking, relationship strengthening, professional development and recognition) and spiritual needs (e.g., personal and cultural development). The item pool was developed based on this theoretical basis.

A pool of 77 initial items was constructed. The initial items were refined and edited for content validity by one academic faculty member. An expert judgment is generally recommended as a general technique of item generation (DeVellis, 2003; Netemeyer, Bearden, \& Sharma, 2003).

In the empirical study the items that have appropriate reaction and discrimination indices will be selected. The factorial validity will be established. Based on principal component analysis the scales will be determined. The internal consistency of scales will be cheked (Kline, 2000).

The research question is: Do psychometric properties of the TNQ satisfy reliability and validity criteria of psychometrics? 


\section{Method}

\section{Participants}

The sample consisted of 237 participants aged from 17 to 68 years $(26.2 \%$ male, $73.8 \%$ female, mean age $M=30.49, S D=9.21$ ) with native Russian language; $38 \%$ participants were from Russia, $11.4 \%$ - from Latvia, and $50.6 \%$ - from other countries.

\section{Instrument}

Travelers Needs Questionnaire (TNQ). The first item pool consisted of 77 items, however, based on the results of the psychometric analysis, the number of items was reduced to 28. Responsesaremadeon a 4-point Likertscale (4 important, the main aim of my travel, 3 - important, if it possible I would like to combine it with main aim of my travel, 2 - not so important, I can refuse it, 1 not important, there is no need for it). The questionnaire is in Russian.

Items examples: "To get professional recognition" (N31), "To visit holy places" (N18), "To think about my life" (N29), "To visit museums, exhibitions" (N34), "To move more" (N67), "To take pleasure in comfortable conditions" (N40), To spend time in the company of people, whose hobbies coincide with mine" (N9).

\section{Procedure}

Data was collected on a voluntary basis via internet (http://cheaptriptest.itmclient.com/) from December 15, 2013 to August 31, 2014. All participants filled out the test on-line.

\section{Results}

The newly established TNQ consists of 28 items that form seven scales: Professional Realization $(k=4)$, Pilgrimage $(k=4)$, Personal Development $(k=$ 4), Cultural Development $(k=4)$, Sport $(k=4)$, Physical Hedonism $(k=4)$ and Communication $(k=4)$.

\section{Descriptive statistics and reliability}

Cronbach's alpha coefficients for all scales of the TNQ were computed. The coefficients ranged from .72 to .90 , so that it could be said that reliability for all scales was acceptably high (see Table 1) (Cronbach, 1984; Standards for Educational and Psychological Testing, 1985; Crocker \& Algina, 1986; Kline, 2000). 
Proceedings of the International Scientific Conference. Volume I, May $27^{\text {th }}-28^{\text {th }}, 2016.422-430$

Table 1 Descriptive statistics and reliability indices for the TNQ

\begin{tabular}{lcccc}
\hline \multicolumn{1}{c}{ Scaleof TNQ II } & $\begin{array}{c}\text { Number } \\
\text { of } \\
\text { items }\end{array}$ & $\begin{array}{c}\text { Cronbach's } \\
\text { alpha }\end{array}$ & Mean & SD \\
\hline Professional Realization & 4 & .90 & 7.92 & 3.49 \\
Pilgrimage & 4 & .87 & 7.30 & 3.34 \\
Personal Development & 4 & .86 & 11.54 & 3.35 \\
Cultural Development & 4 & .80 & 12.12 & 2.74 \\
Sport & 4 & .72 & 9.85 & 2.75 \\
Physical Hedonism & 4 & .77 & 9.59 & 2.95 \\
Communication & 4 & .72 & 10.57 & 2.69 \\
\hline
\end{tabular}

Table 2 Item statistics by scale for the TNQ

\begin{tabular}{|c|c|c|c|c|c|c|c|c|c|c|c|}
\hline Item & $M$ & $S D$ & $\begin{array}{l}\text { Corrected } \\
\text { Item-Total } \\
\text { Correlation }\end{array}$ & Item & $M$ & $S D$ & $\begin{array}{l}\text { Corrected } \\
\text { Item-Total } \\
\text { Correlation }\end{array}$ & Item & $M$ & $S D$ & $\begin{array}{l}\text { Corrected } \\
\text { Item-Total } \\
\text { Correlation }\end{array}$ \\
\hline \multicolumn{4}{|c|}{ Professional Realization } & \multicolumn{3}{|c|}{ Pilgrimage } & & \multicolumn{4}{|c|}{ Personal Development } \\
\hline N31 & 1.89 & 1.00 & .81 & N18 & 1.96 & 1.07 & .82 & N29 & 2.82 & .90 & .78 \\
\hline N48 & 1.99 & 1.02 & .81 & N7 & 2.02 & 1.07 & .76 & N26 & 2.93 & 1.02 & .74 \\
\hline N74 & 1.90 & .99 & .79 & N57 & 1.60 & .87 & .74 & $\mathrm{~N} 43$ & 2.89 & .90 & .74 \\
\hline N10 & 2.14 & .98 & .68 & N38 & 1.72 & .92 & .59 & N3 & 2.90 & .97 & .59 \\
\hline $\begin{array}{l}\text { Scale } \\
\text { mean }\end{array}$ & 1.98 & & & $\begin{array}{l}\text { Scale } \\
\text { mean }\end{array}$ & 1.83 & & & $\begin{array}{l}\text { Scale } \\
\text { mean }\end{array}$ & 2.89 & & \\
\hline \multicolumn{4}{|c|}{ Cultural Development } & \multicolumn{3}{|l|}{ Sport } & & \multicolumn{4}{|c|}{ Physical Hedonism } \\
\hline N34 & 3.01 & .95 & .71 & N67 & 3.02 & .84 & .53 & $\mathrm{~N} 40$ & 2.96 & .93 & .56 \\
\hline N45 & 3.03 & .89 & .70 & N76 & 2.66 & .94 & .57 & N73 & 2.31 & .97 & .60 \\
\hline N21 & 2.81 & .85 & .62 & N4 & 1.81 & .93 & .55 & N6 & 1.99 & .95 & .59 \\
\hline N47 & 3.27 & .77 & .42 & N71 & 2.35 & 1.02 & .38 & N70 & 2.33 & .98 & .54 \\
\hline $\begin{array}{l}\text { Scale } \\
\text { mean }\end{array}$ & 3.03 & & & $\begin{array}{l}\text { Scale } \\
\text { mean }\end{array}$ & 2.46 & & & $\begin{array}{l}\text { Scale } \\
\text { mean }\end{array}$ & 2.40 & & \\
\hline \multicolumn{12}{|c|}{ Communication } \\
\hline N9 & 2.84 & .93 & .56 & & & & & & & & \\
\hline N49 & 2.97 & .81 & .55 & & & & & & & & \\
\hline N8 & 2.88 & 1.01 & .56 & & & & & & & & \\
\hline N16 & 1.88 & .86 & .36 & & & & & & & & \\
\hline $\begin{array}{l}\text { Scale } \\
\text { mean }\end{array}$ & 2.64 & & & & & & & & & & \\
\hline
\end{tabular}

Items reaction and discrimination indices satisfied the psychometric criteria (see Table 2). Items of the TNQ showed good reaction indices. The average reaction index was 2.46. Coefficients of correlations between each item and the sum of the remaining items in the scale ranged from .36 to .82 , and in most cases were moderately high or high.

Factorial validity

Seven factors of the TNQ are yielded using principal component analysis with Varimax rotation. The KMO measure was .76, and the Bartlett test was significant $\chi^{2}(378)=3238.65(p=.00)$. 
The component analysis of the items supported the factors the TNQ was designed to measure. The component matrix for the seven-component solution is shown in Table 3. All components had high loadings for items from equivalent TNQ dimensions and could be identified as Professional Realization (C1), Pilgrimage (C2), Personal Development (C3), Cultural Development (C4), Sport (C5), Physical Hedonism (C6), Communication (C7).

Table 3 Results of Principal Component Analysis with a Varimax Rotation for the TNQ

\begin{tabular}{|c|c|c|c|c|c|c|c|}
\hline \multirow[t]{2}{*}{ Variable } & \multicolumn{7}{|c|}{ Component Loadings } \\
\hline & $C 1$ & $C 2$ & $C 3$ & $C 4$ & C5 & C6 & C7 \\
\hline \multicolumn{8}{|l|}{$\begin{array}{l}\text { Professional } \\
\text { Realization }\end{array}$} \\
\hline N31 & .88 & .04 & .12 & .05 & .08 & .08 & .08 \\
\hline N48 & .87 & .04 & .13 & .02 & .13 & .11 & .08 \\
\hline N74 & .86 & .11 & .02 & -.01 & .20 & .14 & .09 \\
\hline N10 & .77 & .17 & -.03 & .09 & .03 & .05 & .24 \\
\hline \multicolumn{8}{|l|}{ Pilgrimage } \\
\hline N18 & .06 & .90 & .06 & .07 & .09 & -.04 & .06 \\
\hline N7 & .03 & .85 & .13 & .11 & .02 & .02 & .11 \\
\hline N57 & .11 & .82 & .03 & .03 & .08 & .26 & -.13 \\
\hline N38 & .17 & .68 & .21 & -.02 & .18 & .15 & .04 \\
\hline \multicolumn{8}{|c|}{ Personal Development } \\
\hline N29 & .11 & .09 & .86 & .02 & .14 & -.07 & .01 \\
\hline N26 & .05 & .11 & .85 & .05 & .02 & .01 & -.04 \\
\hline $\mathrm{N} 43$ & .05 & .14 & .83 & -.02 & .15 & .14 & .03 \\
\hline N3 & .01 & .05 & .74 & .15 & .07 & .03 & .05 \\
\hline \multicolumn{8}{|c|}{ Cultural Development } \\
\hline N34 & -.03 & .01 & -.05 & .87 & -.02 & .07 & -.01 \\
\hline N45 & .06 & .07 & .09 & .84 & -.04 & -.04 & -.04 \\
\hline N21 & .01 & .09 & .03 & .79 & -.09 & .04 & .09 \\
\hline N47 & .11 & -.01 & .18 & .58 & .27 & -.11 & -.04 \\
\hline \multicolumn{8}{|l|}{ Sport } \\
\hline N67 & -.02 & .03 & .01 & .20 & .78 & -.07 & .01 \\
\hline N76 & .16 & .03 & .14 & -.04 & .76 & .24 & -.04 \\
\hline N4 & .09 & .07 & .11 & -.09 & .76 & .06 & .02 \\
\hline N71 & .17 & .21 & .11 & -.04 & .53 & -.02 & .07 \\
\hline \multicolumn{8}{|l|}{ Physical Hedonism } \\
\hline N40 & .02 & -.06 & -.02 & .06 & -.11 & .82 & .17 \\
\hline N73 & .25 & .05 & -.04 & .11 & .00 & .77 & .11 \\
\hline N6 & .03 & 27 & .07 & -.18 & .19 & .67 & .16 \\
\hline N70 & .14 & .32 & .21 & -.07 & .30 & .63 & -.01 \\
\hline \multicolumn{8}{|l|}{ Communication } \\
\hline N9 & .18 & -.01 & .12 & -.01 & .03 & -.06 & .79 \\
\hline N49 & .07 & -.06 & .06 & -.04 & -.04 & .11 & .78 \\
\hline N8 & .04 & .04 & .01 & -.02 & .01 & .20 & .77 \\
\hline N16 & .14 & .17 & -.16 & .10 & .10 & .14 & .52 \\
\hline $\begin{array}{l}\text { Components' } \\
\text { eigenvalues after } \\
\text { rotation }\end{array}$ & 3.14 & 3.04 & 2.99 & 2.60 & 2.43 & 2.43 & 2.29 \\
\hline $\begin{array}{l}\% \text { of variance after } \\
\text { rotation }\end{array}$ & 11.20 & 10.87 & 10.67 & 9.28 & 8.67 & 8.66 & 8.16 \\
\hline
\end{tabular}




\section{Discussion}

This study investigated the reliability and the factorial structure of the Travelers Needs Questionnaire (TNQ). The inner structure of the developed TNQ is characterized by a clearly interpretable seven-factor structure. The obtained factors can be interpreted as Professional Realization, Pilgrimage, Personal Development, Cultural Development, Sport, Physical Hedonism and Communication.

Two factors (Sport and Physical Hedonism) can be categorized as physical needs. Two factors (Professional Realization and Communication) were categorized as social needs. At last three factors (Pilgrimage, Personal Development and Cultural Development) can be categorized as spiritual needs.

In general, the results of the present study, namely, the revealed interpretable factors and their further categorization as psychical, social, and spiritual needs of travelers, are consistent with other researchers' findings (e.g., McIntosh et al., 1995; Pearce, 2005) which demonstrated that physical, social, and spiritual motivators among other sare central for understanding of tourists' interests and activities.

For instance, as mentioned above, McIntosh and co-authors (McIntosh et al., 1995) have found four categories of motivators, namely, physical, cultural, interpersonal and status and prestige motivators. Two factors, which were found in this study, namely, Sport and Physical Hedonism, correspond to physical motivators discovered by McIntosh and co-authors. Two our factors Professional Realization and Communication - refer to McIntosh's and coauthors' status and prestige motives and interpersonal motives respectively. One factor, which is found in our study, namely, Cultural Development, correspond to cultural motives described by McIntosh and co-authors. Additionally, in this study such factors were revealed as Pilgrimage and Personal Development, which we can't to refer to any of four categories described by McIntosh and coauthors. We categorized these two factors together with Cultural Development as spiritual needs.

The factors, which were revealed in our study and characterize different travelers' needs, can be also compared to motivation factors identified by Pearce and Lee (Pearce \& Lee, 2005). Particularly, in both empirical studies such motivation factors were found as (1) self-development, namely, Professional Realization in our study and self-development (self-enhancement) in the study conducted by Pearce and Lee; (2) self-actualization - Personal Development in our study and self-actualization in the study conducted by Pearce and Lee; (3) experiencing different cultures - Cultural Development in our study and selfdevelopment (host-site involvement) in the study conducted by Pearce and Lee; 
(4) relationship - Communication in our study and enhancement and security of relationship in the study conducted by Pearce and Lee.

In summary, it is possible to conclude that travelers' needs identified in this study at least partly correspond to motivation factors identified by other authors in previous studies.

In this study the psychometric properties of the TNQ confirm that it is a reliable instrument for its use. The study showed that internal consistency of the TNQ was satisfactory. The TNQ has shown to be reliable and valid travelers needs measure suitable for Russian cultural context. The further stage of TNQ development would be the confirmatory factor analysis in broader international sample, the concurrent and convergent validity establishing, and test-retest reliability examination. Taking into account that the TNQ was developed in Russian in future it will be also valuable to adapt the test into other languages to make it appropriate for use by travelers in Ukraine, Belarus, and the Baltic States with other native languages.

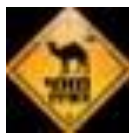

\section{This work has been supported by the Cheaptrip.}

\section{References}

American Educational Research Association (AERA), American Psychological Association (APA), and the National Council on Measurement in Education (NCME). (1999). Standards for educational and psychological testing. Washington, D.C.: American Psychological Association.

Crocker, L., \& Algina, J. (1986). Introduction to classical and modern test theory. New York: CBS College Publishing.

Crompton, J. L. (1979). Motivation for pleasure vacation. Annals of Tourism Research, 6, 408-424.

Crompton, J. L., \& McKay, S. L. (1997). Motives of visitors attending festival events. Annals of Tourism Research, 24, 425-439.

Cronbach, L. J. (1984). Essentials of psychological testing (4th ed.). New York: Harper and Row.

DeVellis, R. F. (2003). Scale development: Theory and applications. London: Sage Publications.

James, W. (1890). The principles of psychology. New York: Henry Holt and Company, pp. 291-401.

Kline, P. (2000). The handbook of psychological testing (2nd ed.). London: Routledge.

Kim, Y. G., \& Eves, A. (2012). Construction and validation of a scale to measure tourist motivation to consume local food. Tourism Management, 33, 1458-1467.

Maslow, A. H. (1970). Motivation and personality. New York: Harper \& Row.

Matzler, K., \& Siller, H. J. (2003). Linking travel motivations with perceptions of destinations: The case of youth travelers in Alpine summer and winter tourism. Tourism Review, 58 (4), 6-11. 
Proceedings of the International Scientific Conference. Volume I, May $27^{\text {th }}-28^{\text {th }}, 2016.422-430$

McIntosh, R. W., Goeldner, C. R., \& Ritchie, J. R. (1995). Tourism principles, practices, philosophies (7th ed.). New York: Wiley.

Mohr, K., Backman, K. F., Gahan, L. W., \& Backman, S. J. (1993). An investigation of festival motivations and event satisfaction by visitor type. Festival Management and Event Tourism, 1 (3), 89-97.

Moscardo, G., Morrison, A. M., Pearce, P. L., Lang, C. T., \& O’Leary, J. T. (1996). Understanding destination vacation choice through travel motivation and activities. Journal of Vacation Marketing 2 (2), 109-122.

Moscardo, G., \& Pearce, P. L. (1986). Historical theme parks: An Australian experience in authenticity. Annals of Tourism Research, 13 (3), 467-479.

Netemeyer, R. G., Bearden, W. O., \& Sharma, S. (2003). Scaling procedures: Issues and applications. London: Sage Publications.

Nuttin, J. (1962). Psychanalyseet conception spiritualiste de I'homme. Paris, P.U.F.

Pearce, P. L. (1988). The Ulysses factor: Evaluating visitors in tourist settings. New York: Springer-Verlag.

Pearce, P. L. (1993). Fundamentals of tourist motivation. In D. Pearce \& R. Butler (Eds.), Tourism research: Critiques and challenges (pp. 85-105). London: Routledge and Kegan Paul.

Pearce, P. L. (2005). Tourist behaviour: Themes and conceptual schemes. Channel View Publications.

Pearce, P. L., \& Caltabiano, M. L. (1983). Inferring travel motivation from travelers' experiences. Journal of Travel Research, 23 (3), 576-598.

Pearce, P. L., \& Lee, U. (2005). Developing the traveler career approach to tourist motivation. Journal of Traveler Research, 43, 29-39.

Uysal, M., Gahan, L., \& Martin, B. (1993). An examination of event motivations: A case study. Festival Management and Event Tourism, 1, 5-10.

Wahab, S. E. (1975). Tourism management. London: Tourism International Press. 